\title{
Conference Report on Spiritual Abuse: Education and Prevention for our Communities
}

Afshan M. Malik

Rabata

The Ribaat Academic Program, a branch of the larger nonprofit organization Rabata, Inc., which promotes positive cultural change through creative educational opportunities, held an educational webinar on December 16, 2018. As a leading institute for online education that brings traditional Islamic sciences to women worldwide, this program highlighted the topic of spiritual abuse from the standpoints of scholars, educators, and licensed therapists.

Since 2014, this academic program has hosted a multitude of webinars in addition to its semester-length courses in the Islamic sciences. These webinars address modern-day struggles and topics against the backdrop of traditional Islamic teachings. Featured in this one were Shaykha Anse Tamara Gray (Rabata's founder and executive director), Dr. Ingrid Mattson, Ustadha Zaynab Ansari, Ustadha Iesha Prime, Ustadha Sana Mohiuddin, Shaykh Rami Nsour, and Sister Salma Abugideiri, LPC.

Observing that spiritual abuse is a serious community problem to which all men, women, and children are vulnerable, the webinar stated that those involved are often unsure as to what constitutes an unhealthy student-teacher relationship or how to stay professional yet engaged. Therefore, this event was designed to equip attendees with the knowledge of what spiritual abuse really means and how everyone - students, teachers, and community members - can prevent it. The speakers explored the nuances of spiritual abuse, as well as preventative measures, guidelines for parents whose children are in the process of religious and spiritual development, support for victims, and information on what the ideal student-teacher relationship looks like according to the Prophet's (peace be upon him) Sunnah.

The conference was divided into two segments based on the central time zone. The Ribaat Academic Program highlights the importance of having a live attendance, but as its global audience spans several time zones, they clearly advertise the availability of recordings to registrants for all sessions at ribaat.rabata.org. An ongoing dialogue in the associated chat box enables live attendees to have an interactive engagement with and personal access to all speakers. 
Dr. Mattson lectured on understanding spiritual abuse and detailed the various categories of spiritual abusers, such as intentional abusers versus "wanderers" who fall into spiritual abuse by circumstance. She offered a specifically nuanced instruction on how to monitor and alleviate those situations in which spiritual abuse can become a means of manipulating the victim's financial and other actions. Mattson explained the thinking process of spiritual abusers and offered advice about how, on a community scale, the public can call them to account and prevent them from continuing the same habits at different organizations and places of worship.

Protecting religion does not mean protecting mosques and buildings. It means protecting the people of the religion ... Who are we helping when we do not intervene in cases of abuse? No one. We must intervene as individuals and have systems of intervention in place as a community.

She followed this up with a lesson from Umar Ibn al Khattab's legacy in leadership.

If a person was suspected of abuse, Umar ibn al Khattab removed the suspect from his position and then conducted the investigation. No one has a right to a certain position, and removing the potential for more abuse outweighs other considerations.

Shyakh Nsour highlighted the community's role and responsibility in addressing spiritual abuse and gave examples garnered through his own instruction and interaction with abusers as follows: "Recognizing the pattern of behavior is very important. Patterns may indicate criminality." He also shared an insight from the community's history regarding people's behavior by reflecting on the popular hadith by the Prophet

Actions are by their intentions is a true statement [Editor's note: The actual hadith, narrated by Umar ibn al-Khattab, is found in Bukhari and Muslim (http://musliminc.com/hadith-actions-are-byintentions-10185)] - but only Allah knows what someone's intentions really are. Even the Nazis and perpetrators of other large-scale atrocities claimed good intentions. So we have to judge on the outer actions like the Prophet taught us to do. 
Ustadha Mohiuddin and Sister Abugideiri, both practicing therapists, are often called upon to address situations of spiritual abuse in their own communities. Ustadha Mohiuddin gave a lengthy presentation on how to monitor and protect children from being victimized. She addressed those who have the power to influence young minds and recommended that they remind children that no one, absolutely no one, is above God because, as she stated, "Spiritual abuse can happen from anyone who has been granted access: an imam, a scholar, a Sunday school teacher, a mentor we've brought into our home. Watch your children for signs, including their attitude." She also touched on the spiritual dimensions of abuse by advising the audience to "Know that your child's teacher has a metaphysical relationship with him or her. They should be mindful of the child's heart and how they [are] relaying the significance of this sacred text." Explaining that all victims react in different ways, she said, "If children are showing a drastic change in attitude regarding Islam, be mindful of where it's coming from and continue your vigilance as a parent. Be curious, ask questions, have an emotional presence in your child's life."

Sister Abugideiri's session spoke to the victims directly and addressed their pain.

The fact that we've faced abuse does not mean that God loves us any less. It's really important that we don't interpret abuse as a lack of favor from God. We want to stay connected to Him and remember that $\mathrm{He}$ is the most Merciful and knows what is going on with you.

She gave practical advice to both the victims and those individuals who may come into contact with them on how to provide support, help, and access to care. As many victims face trials in faith and God, she noted that people must acknowledge their pain and refrain from judging them.

Shaykha Gray used her session to directly advise religious teachers on how to be proactive in their own behavior in order to limit this particular risk. She encouraged teachers and those people with religious authority to undertake a deep and regular introspection of their roles and responsibilities, for "The beginning of this path is with good intentions. As a religious teacher in any capacity, know that this intention can manifest itself in various ways." As a religious scholar and educator, she connected with her target audience by guiding them in how to perceive their role in people's lives in a deeper context. "Know yourself. Know your personality. If someone comes to you for help and you begin to think that you are the only one who can help them - this is a problem. Everyone is replaceable." 
Ustadha Prime emphasized self-reflection by providing examples from the Sunnah regarding student-teacher relationships. She said that everyone must be aware that they can use their own agency to empower and protect themselves and gave examples of being mindful (e.g., not being alone in a room with someone or engaging in behavior that could be misunderstood). "Spiritual abuse can also happen to groups of people and from same-sex teachers," she highlighted. "Almost cult-like habits can come about within groups where certain acts of service are expected."

Ustadha Ansari stressed self-agency and learning from the legacy of historical Muslim women.

The dignity that Allah has given to you, no one can ever take that away from you. Pay close attention to the strongest examples of women we have - the Mothers of the Believers and the female Companions. Look at their strength, valor, and dignity.

She reminded the audience of how spiritual abuse may manifest through individuals' neglect of cultivating their own relationship with the Divine.

There is no obedience to creation that is elevated over obedience to the Creator. As much as we have a love and respect for our teachers, we have to understand [that] our relationship with God is at a completely different level.

An interactive $\mathrm{Q} / \mathrm{A}$ forum was arranged for those who viewed the recordings and wanted to continue conversations with speakers on various topics that they considered important.

The spiritual abuse webinar was received with great acclaim by participants. The Ribaat Academic Program provides all registrants with access to each webinar recording for 90 days after their registration date. Speaker topics are listed below, and the recordings are available at ribaat.rabata.org.

Speakers \& Topics: Ustadha Sana Mohiuddin: "Protecting our Children," Ustadha Zaynab Ansari: "Protection from Spiritual Abuse," Ustadha Ieasha Prime: “The Sunnah Relationship," Anse Tamara Gray: “Teacher's Guide: How to Establish Relationships \& Set Boundaries," Dr. Ingrid Mattson: "Understanding Spiritual Abuse," Salma Abugideiri, LPC: "Help for Victims," and Shaykh Rami Nsour: "A Community's Responsibility." 